\title{
The trial of Andrei Sawoniuk: Holocaust testimony under cross-examination
}

David Hirsh

\begin{abstract}
Andrei Sawoniuk, a member of a Nazi-organized police outfit, led an operation in a small town in Belorus in 1942-3 to kill the Jews who had evaded the main Nazi massacre. He was found guilty, not of genocide or crimes against humanity, but of murder, according to the War Crimes Act (1991) in a trial in London in 1999. This article explores the ways in which the testimonies elicited were transformed from memoirs of the Holocaust by the rules and norms of the trial process into legally admissible evidence by the processes of cross-examination and of selecting what evidence was suitable to be considered by the jury and what was not. The extraordinariness of the events with which the trial was concerned accentuated the differences between memoir and evidence. The key witnesses in the trial found ways to circumvent the rules of the court and to speak directly to the jury.
\end{abstract}

\section{Introduction}

Andrei Sawoniuk, a member of a local Nazi-organized police outfit, led an operation in a small town in occupied Belorus in 1942-3 to find and kill the Jews who had evaded the main Nazi massacre. He was found guilty under the War Crimes Act (1991) at the Old Bailey in London in 1999.

An issue which was always present in this trial was a marked contrast between ordinariness and extraordinariness. Habermas has argued that 'Auschwitz has become the signature of an entire epoch - and it concerns all of us. Something happened there that no one could previously have thought even possible' (1991: 251-2). The Holocaust was an event so huge that it changed the way human beings understand themselves and the world in which they live. It consisted of horror on an unprecedented scale. The trial of Andrei Sawoniuk, however, was routine and business-like. Sawoniuk himself was in many ways unremarkable yet he became, for a period of a few years 
only, a sadistic mass killer, before reverting to an invisible life as a railway worker.

One issue which was central in his trial was the question of the admissibility and non-admissibility of certain types of evidence. Some strong and arguably illuminating documentary evidence was prevented from going before the jury. The court required direct eye-witness testimony. The narratives presented by the witnesses, particularly those presented by the Jewish survivor who gave evidence, Ben-Zion Blustein, were acted upon and changed by the rules and requirements of a criminal trial. In this article I explore the ways in which memoir was transformed into testimony by the court. Many Holocaust survivors have published memoirs of their experiences during the genocide. There have also been projects to record the experiences of large numbers of survivors in archives. That which can be accepted as evidence in a criminal trial, however, is different from these memoirs. At least, it may start as memoir, but the memoir is acted upon by the rules and norms of the legal processes, particularly by the process of cross-examination and by that of the sifting out of evidence which is deemed to be inadmissible; the trial process is always striving to transform memoir into evidence. Giving evidence in any criminal trial, especially for victims of the crime, must always be difficult. Holocaust survivors are accustomed to being in control of the presentation of their memoir and to being listened to by a supportive audience. For a survivor, the demand that the court makes, that it be allowed to take control of the presentation of memoir, to challenge it and to transform it into what it considers to be evidence, must be particularly difficult. Blustein resisted the court's mechanisms and tried to retain control over his own testimony.

The court had difficulty in bounding the extra-ordinary events and stories which were given to it within the normal rules of criminal evidence. The jury was influenced both by evidence which the court wished it to hear and also by influences which the court wished to suppress. Otto Kirchheimer has pointed out that:

Anglo-American adversary procedure organizes the trial as a battle of wits between the prosecution and defense, with the judge acting as their referee, constantly deciding what line of questioning and what material should be allowed to enter the minds of the jury. Yet the 
judge's authority in this respect may be more official than real: a skilful lawyer will be able to make his point before his adversary can open his mouth to object. The resulting wrangling on admissibility and the judge's ritual exhortation in summing up what points to disregard - for example, the political loyalties of the defendant in an espionage trial only make the forbidden fruit more tempting to the jury than all the rest. (1969: 342)

The trial was a struggle between witnesses, the defendant, the defence and prosecution lawyers and the judge for control over the information which the jury would use to come to its verdict.

\section{The ordinary and extraordinary Andrei Sawoniuk}

Sawoniuk was, in many senses, an ordinary man. Aged 78 at the time of his trial, his hair was white and carefully barbered. He had a round baby face with blue-grey eyes peering through his up-to-date glasses. He was always dressed smartly, in a blazer, creased trousers and shiny shoes like the old Polish soldier and British Rail ticket collector that he was. He limped with a stick, but did not seem particularly fragile. He seemed to be a man who knew how to look after himself. He sat in court next to his solicitors, not in the dock, since he was on bail. He followed the transcript of the proceedings as it appeared on the lap-top computer in front of him. He occasionally whispered, rather loudly, perhaps because of his partial deafness, to his solicitors. They seemed friendly and called him Tony. Not once in the whole trial did he look to his right toward the press gallery, or, above that, the public gallery.

He was born in Domachevo, a small, ordinary town, which is currently in Belorus, near Brest-Litovsk, and was just inside the Polish border of the old Soviet Union. When he was born there on 7 March 1921, it was in Poland. Domachevo's main business was tourism. It had a spa and some hotels and guest houses. Domachevo conformed to the ethnic division of labour which was common in Eastern Europe. The town itself was almost entirely Jewish while the surrounding villages where the peasants cultivated the land were almost entirely non-Jewish. The Jews supplied goods and services to the farmers, as well as to visitors. The farmers sold their produce to the Jews in the market. As well as the Russian Orthodox church in Domachevo there was 
also a Catholic church, where those who considered themselves Polish worshipped.

Sawoniuk himself was born and lived his childhood outside of the established division of labour, or perhaps underneath it. His family did not have land to tend and so they lived in the town itself. His mother made a meagre living by doing laundry and other casual work for Jews, and when he was old enough, he also worked for Jews, doing odd jobs when he could find them. He never knew his father, and his mother died when he was a child. He was regularly called a 'bastard' and was subjected to a certain amount of bullying on that account. After his mother died he lived with his grandmother and brother, Kola. For these reasons he must have experienced a certain amount of alienation from the society in which he lived and in which he did not really have an established place. He left school at the age of 14. He was known by everyone in Domachevo simply as Andrusha, a diminutive of Andrei. Little Andy. He was still known by this diminutive when he was the commandant of the local Nazi-organized police force.

The German invasion of Russia started on mid-summer night, 1941 and within hours had swept well past Domachevo which was one of the first small towns it encountered. Within a very few days, the Germans had organized a local police force which Sawoniuk and a handful of other local men joined enthusiastically. He was 20 years old and had experienced two very difficult years under Russian occupation. For the first time in his life he had a job, and a place in the world.

Sawoniuk has lived in Britain since 1946. He moved around a little, mainly on the South Coast before settling in London, just off the Old Kent Road. He worked for British Rail, and retired in 1986. He married twice after the war, both short marriages, and had a son with his second wife, but they parted shortly after his birth. In Britain he has been, as the police testified, 'of good character'. On 9 March 1999 he appeared in court no. 12 at the Old Bailey. In many ways it was a routine trial. The defendants in the courts next door were accused one of rape and the other of murder. There was no glass dock to 
protect him from assassination. There was no simultaneous translation apparatus in the court room. It was the usual British court room. Sawoniuk was not accused of anything exotic or un-British like genocide or crimes against humanity. He was accused of four counts of murder 'contrary to the common law' under the conditions specified in the War Crimes Act (1991). It may have been true that if Sawoniuk had been charged with the crime of genocide or with crimes against humanity, then the court would have been able more easily to take into account the whole story which emerged about Sawoniuk's conduct during the war. It would not have been necessary to focus exclusively on the four counts of murder, only two of which survived to go before the jury. It would have been possible to take into consideration other evidence which added to the picture of Sawoniuk as a Nazi killer. Perhaps, even if it had been impossible to prove specific murders, it still might have been possible to convict him of being part of the common plan or criminal conspiracy to kill the Jews of Europe. The ad hoc tribunals for the former Yugoslavia and for Rwanda have recently convicted for both genocide and crimes against humanity; ${ }^{1}$ Belgium has shown that it is possible for national courts to make convictions for genocide (Le Monde 2001). The International Criminal Court Bill (2001) currently going through the British parliament also makes provisions for extradition and trials in British law for genocide and crimes against humanity. The fact that the charges against Sawoniuk were simply murder added to the impression that this trial was an ordinary Old Bailey trial.

\section{Crimes against humanity}

For the individuals involved in the rape and murder trials in the neighbouring courts, however, those cases were in no way routine or mundane. They concerned events which must have made profound changes to the lives of those affected. Criminal trials give extraordinary events a routine form; they abstract them, shape them and civilize them. The rapist and the murderer, as well as Sawoniuk, both wore shiny shoes and well-pressed suits. Their counsel spoke for them eloquently and persuasively. The judges politely offered them drinks of water. So if the Sawoniuk trial was made to look 
routine, then that is partly because that is a general function of a criminal trial. But the contrast between the business-like quality of the trial and the horror of the events which it concerned was greater because the events were extraordinary in a more profound sense than an ordinary rape or murder. Crimes against humanity are qualitatively, not just quantitatively, different from ordinary murder or rape. ${ }^{2}$ The Nazis were not simply unwilling to share Germany with the Jews; they were unwilling to share the earth with them. Genocide is, in the words of Edgar Faure, a 'criminal enterprise against the human condition' (Finkielkraut, 1992: 28). As Arendt puts it, genocide is:

an attack upon human diversity as such, that is, upon a characteristic of the 'human status' without which the very words 'mankind' or 'humanity' would be devoid of meaning. (1994: 268-9)

Genocide is a crime against every individual on the earth because it is an attack on each person's status as a human being. This juxtaposition between the ordinary and the extraordinary is a theme which runs throughout this particular trial and it echoes a similar dialectic which many have detected within the Holocaust itself. Claude Lanzmann (1985), in his film Shoah, is fascinated by the ordinariness of the trains which transported so many to their deaths. Zygmunt Bauman (1993) focuses on the bureaucratic individuals and procedures which organized the mass killing, arguing that it was social mechanisms which are entirely commonplace in our society which conceived and executed the genocide and that it was simply a re-configuration of those ordinary mechanisms which produced the extraordinary result. In Nazi Germany:

Government was conducted through a centralised, hierarchical and bureaucratic state; respect was afforded to science, knowledge and expertise; rational behaviour was valued over irrational behaviour; the breaking down of tasks into small parts was prevalent; the technology of factories and railways was well established. (Fine and Hirsh 2000: 186)

Jaspers (1992) and Arendt (1994) have written about the banality of evil, noticing that unprecedented crimes could be committed by banal individuals; they have discussed the idea that the prosecution of mass murderers as mere 
criminals would remove their aura of satanic greatness and expose them in all their banality (Fine, 2000).

Sawoniuk was an ordinary kid, a nobody, who joined the police force in order to become a somebody. When the real function of the police force became clear, some, including his brother, left; he chose to stay. When the Einsatzgruppe came to town to kill the Jews on Yom Kippur 1942, Sawoniuk helped. The Nazis left to kill the Jews in the next town and the local police were left the job of hunting and killing those who had escaped the main massacre. Sawoniuk took a central part in this hunt and kill operation for a few months until it was complete. Maybe he killed 50 or 100 or 200 Jews at this time and he did so with more enthusiasm than most. There must have been many tens of thousands just like him. They were a necessary part of the machine which committed the genocide. It was the locally recruited police forces who knew the Jews, and who knew where they might be hiding much better than the invaders did. When it was all over, he found a life for himself in Britain, and lived it.

Inevitably, the trial raised the question of responsibility for the genocide. Who was responsible? Who can be responsible for a crime so huge that it can only be perpetrated by the mobilization of the resources of a whole state ${ }^{3}$ It was the function of the court of law to extract Antony Sawoniuk from the enormous machine of the Third Reich. The Nazi movement committed the crime, yet in a court, the individuals who were part of that movement are transformed from footsoldiers and bureaucrats back into responsible human beings. The extraordinary history of Europe had transformed Sawoniuk as a young man from an ordinary human being into a sadistic killer. He had succeeded in transforming himself back into an unremarkable railway worker after the war. But the court demanded more of him. It demanded that he take responsibility for those crimes he had committed during the time when he was part of the genocide machine.

At one point during his cross-examination Sawoniuk lost his temper. He shouted at the jury: 'Andrusha Andrusha Andrusha. They say only Andrusha 
Andrusha. No-one else killed no-one. Only Andrusha. Everyone else just watches and claps. Only they pick on me' (22/03/99). Nutting, the prosecution barrister, might have replied 'No, Mr. Sawoniuk, it isn't fair, is it? So many were guilty and it is only Andrusha who stands trial....' There must be many thousands of old men in Europe who committed crimes worse than those committed by Sawoniuk. Some of the members of the Einsatzgruppe who actually committed the main massacre in Domachevo must still be alive, reading about the case in the newspapers. So Sawoniuk is certainly unlucky to be held accountable in this way.

Some of the many problems which arose in this case arise routinely in crimes against humanity investigations, while some of them are specific to this trial. In an ordinary murder investigation, the police may have control of the crime scene, often very soon after the crime is committed. This is unlikely to be the case where the crime is being carried out by a social formation which has state power. Thus the immediate identification and interviewing of witnesses and suspects will often be more difficult, as will the gathering of fresh forensic evidence. Another difference is that in an ordinary murder investigation, it is unlikely that there will be widespread support for the murder among potential witnesses, as there may be in these cases. In the Sawoniuk case nearly all the possible Jewish witnesses were dead, as a result of the crime. In the Sawoniuk case, the crime was being investigated by the British police, but within the jurisdiction of Belorus and of Poland. Potential witnesses were always interviewed in the presence of officials of the local state. Sawoniuk's Barrister, William Clegg, said ${ }^{4}$ that he felt that potential defence witnesses were intimidated by local officials, who were keen to secure conviction. This intermeshing of different jurisdictions is likely to be a common source of problems in these cases. The jurisdiction which is carrying out the investigation does not have state power.

There was a further problem in the Sawoniuk case: that is the problem of the trial taking place so long after the crime. All the witnesses were elderly, struggling to recall details of traumatic crimes which they committed, witnessed, or suffered from as young people. Their memories must be 
mediated by 57 years of remembering and re-telling their stories; and of hearing and telling accounts, gossip, and accusation. The accuracy of the memory of witnesses is often an important issue in criminal trials; the problem was exacerbated in this trial by the unusually long time gap between crime and trial.

\section{The difference between memoir and legally admissible}

\section{Evidence}

Ben-Zion Blustein was the first witness to be heard. He seemed to me to be a very typical Jewish Holocaust survivor. He appeared tough, but now old; a little stiff. He had a definite confidence in his story, combined with a nervous vulnerability: the vulnerability of one who knows that nothing in life is safe and that no safety is absolute. Many Holocaust survivors have a typical way, genre perhaps, of telling their story. What made Blustein so uncomfortable in the Old Bailey was the fact that he was not allowed to tell his 'usual story'. Blustein has told his story often. He has told it at Yad Vashem, the Holocaust museum in Jerusalem, where they keep an archive of survivor testimony. He has told it to a ghost writer who wrote it into a book. He has told it to students and to school children. He has told it to family and to friends.

Primo Levi (1987) writes of the way in which his inner drive to tell of what happened at Auschwitz was part of his motivation for keeping alive there. He also writes of the importance of testimony, and of the importance of being believed. His recurring nightmare at Auschwitz was to tell his story to friends and family and for people simply to ignore his voice, not to hear his voice. The fear that people on the 'outside', in the 'real world', would be incapable of even hearing of another universe. The fear that Auschwitz was literally, another universe. It is certain that when Blustein tells his story in Israel, he is met with silence, with sympathy, and with sorrow. He is a survivor-hero in Israel, among Jews, indeed, among anyone who has any kind of human feeling and who hears his story. However, a court of law is not guided by human feeling, it is guided by its own rules and function. The court was not centrally interested in Blustein, it was focused on Sawoniuk. The court was 
not interested in the thousands of dead Jews of Domachevo, but in the 21 Jews who were represented in the indictment. The prosecution was only interested in the parts of Blustein's story that it wished to use to construct the case against Sawoniuk. It was not interested in Blustein's dreams and his fears and his demons. It was not interested in his philosophising or his anger, or his last conversation with his mother. Cross-examination is Primo Levi's nightmare come to life. An educated, intelligent articulate man is paid by the state, in the interests of the Nazi killer, to act the part of the friend who refuses to hear.

The British court was making great efforts to appear disinterested and neutral; simply balancing the arguments. When the jury had been sworn in at the beginning, they were told that if any of them had relations who had suffered in the Holocaust, they should excuse themselves from service. Probably, then, there were no Jews in the jury; Jews were considered unsuitable to serve in such a jury. Jews, as witnesses, or as jurors, were suspected of being unable to 'put aside their feelings', as the jury was asked to do, both by the prosecution and the defence in summing up. It seemed to me that Blustein was one of those Israelis who feels that the only safe place for Jews is Israel, more particularly that Israel is the only safe place for him. So being a witness in this court and undergoing cross-examination must have been, and appeared to be, an unpleasant and uncomfortable job for him.

Dan Stone (2000) writes about Holocaust memoir, and the ways in which many historians of the Holocaust have under-valued survivor testimony in relation to more 'solid' types of evidence such as documentation. JeanFrançois Lyotard has argued that a part of the enormity of the crime of the Shoah was that it eradicated the witnesses and the evidence, it made it impossible to exactly re-construct or represent the events.

Stone quotes Lyotard as follows: 'The "perfect crime" does not consist in killing the victim or the witnesses... but rather in obtaining the silence of the witnesses, the deafness of the judges, and the inconsistency (insanity) of the testimony' (2000: 220). He adds that: 
In other words, it is the attempt to gain cognitive control over the events of the Holocaust, to master them by fitting them into existing narrative frameworks...that really constitutes a 'wrong' (tort) to the victims. In attempting to counter this wrong, Lyotard puts forward the notion of the Holocaust as a sublime event, as 'sign of history' which must be 'felt' rather than known because the magnitude of the event has rendered the usual instruments of measurement obsolete. (2000: 220)

Stone argues that survivor testimonies, full of both traumatic truth and factual inaccuracies, transcend traditional forms of writing histories. That:

testimonies make more clear than other evidence why the excess of the Holocaust breaks the bounds of 'normal' philosophy of history, ... and that this is the primary reason why historians tend to shy away from testimonies... (2000: 229)

Many have been critical of attempts to capture the Holocaust, or elements of it by means of representation. Hence Adorno's (1973) proposition that there can be no poetry after Auschwitz. Hence Claude Lanzmann's refusal to use archive footage or reconstruction in Shoah (1985) and his outrage at Spielberg's Hollywood production.

The court required a different method of finding and understanding the truth. Different to Jean-François Lyotard's 'feeling' of the event; different from survivor memoir; different from Lanzmann's cinematic presentation of carefully produced and edited memoir; different from Spielberg's representation; different from academic historical investigation.

Academic historical representation and analysis of documentary evidence was fine for briefing the jury on the background to the crimes of Sawoniuk, and this task was carried out by Christopher Browning. However, to convict the defendant the court required direct witness testimony. This testimony, it is hoped, is rendered profoundly different from the memoirs of survivors by the process of cross-examination. Documentary evidence, so valuable to historians, was rendered inadmissible by the court in the absence of the testimony of the individual who created the document. 
One document in particular, which was discovered in a German archive, later became the subject of much argument. It was a document which threw light on Sawoniuk's story in the period after his time as a policeman in Domachevo when he committed the crimes of which he was accused by the court. The document showed that he had retreated with the German forces when they were pushed out of the region by the Russian counter-offensive, and that he quickly became a member of the Belorussian unit of the SS. The judge ruled that this document was inadmissible as evidence since its authenticity could not be verified by a direct eye witness; presumably the creator of the document was long dead. This document did not help us to know whether Sawoniuk was guilty of the four counts of murder in Domachevo. But it did tell us that he was, or became, a Nazi; and that he won sufficient trust from the SS while he was in Domachevo for them to recruit him as a member. Moreover, there is evidence to suggest that this unit of the SS was later involved in perpetrating atrocities in the Warsaw region. And it was subsequently moved to France to conduct the war against the partisans, a job which Sawoniuk had been so enthusiastically learning in Domachevo. And it was in France where Sawoniuk turned up and joined the Free Polish Army, telling them that he had been a member of the SS. We know this from another document, his Polish army record, which was also inadmissible. We also know that this unit of the ss suffered from many desertions in France at this time.

These two documents on their own might be enough for an observer who was persuaded that they were genuine, to come to the decision that Sawoniuk was, at least, a Nazi and almost certainly a mass killer. The jury was allowed to know none of this. I do not know, either, how many other incriminating but inadmissible documents were turned up by the police investigation. The prosecution, in fact, managed to leak some of this information to the jury during its cross-examination of Sawoniuk, but technically, this evidence was inadmissible and the jury was instructed to ignore it by the Judge in his summing up. So, for the court, documentary evidence is not sufficiently safe evidence on which to base a conviction. But the eyewitness evidence which is required is given in specific and controlled circumstances. The evidence must 
be immediate, must be given in person, and must be available for crossexamination.

In the appearance of Blustein as a witness, we can see the difference between the memoir and oral testimony of a survivor-hero, and the admissible legal evidence required by a court of law. The court listened in silence to Blustein's shocking testimony as he described, in detail, the German invasion, the ghettoization of the Jews, the main massacre on Yom Kippur 1942, how he hid with his family, how they had unsuccessfully attempted suicide, and how eventually, Blustein had been taken prisoner and forced to work at the German base. He was tired and emotional. The mediation of the interpreter made everything more difficult and slow. This was Blustein's Holocaust memoir. Blustein wanted to tell his story and the story of his family and of the Jews of Domachevo. All the emotion made the court, the legal process, uncomfortable. Blustein wanted to tell his story, but the court wanted to hear 'evidence'. Only at the end of his testimony did Blustein mention Andrusha, in passing. He told that he had seen a gang of local police harass a Jew called Shaya Idel, after the main massacre, and take him off towards the execution site; he mentioned that Sawoniuk was present. Sawoniuk was not charged with killing Shaya Idel. Yet Blustein, with one remark, had clearly implicated him in this murder. The jury was being presented with 'inadmissible' evidence as to Andrusha's guilt in a murder of which he was not accused. When, in the end, the jury came to consider Sawoniuk's guilt or innocence for remaining charges, they must have been influenced by evidence such as this. In normal life, we put together many disparate pieces of 'doubtful' evidence to make a whole. We add them up. In court, doubtful evidence detracted from, rather than added to, to the clarity of the truth.

While Blustein was working at the German base, he saw a Jewish friend of his, Mir Barlas, after he had been captured and interrogated. The murder of Mir Barlas constituted Count 4 of the indictment against Sawoniuk.

B I was looking after the horses at night. Andrusha entered for warmth. He said 'don't think you'll live forever'. When the Germans leave they'll hand you over to us. 'We'll massacre you as we've massacred many.' (24/02/99) 
Sawoniuk went on to tell Blustein that Barlas had been brave before he had been shot. Blustein's evidence was entirely credible. No one, usually, would either wish, or dare, to question a word of it. But it was the job of Sawoniuk's barrister to do so and he managed to create some doubt as to Blustein's accuracy, and even, as to his honesty. Blustein was cross-examined for two days in a fascinating confrontation. Blustein's characteristic response to cross-examination over detail was 'It doesn't matter to me!' or 'I was not interested in such things'. Blustein was interested in the killing of the Jews and of his family. The court was interested in Sawoniuk, the four counts, and various details, which may have been important.

There were three measures that Clegg possessed with which he could test Blustein's story. One was his client's story. This was not very useful to him, since he must have been well aware that his client was lying about almost everything. The second was to test Blustein's evidence against its own internal consistency. The third was to test Blustein's evidence in this court against previous versions of his testimony. Blustein claimed too much. $\mathrm{He}$ claimed that his evidence was infallible in every respect. He used the word 'holy' to describe it. He did not trust the court to assess his evidence fairly, to use its judgement in interpreting his honesty. So he claimed that every single word was exactly true. Clegg had little difficulty in comparing his words at the Old Bailey with his words the year before in the Magistrates' Court, and his original statement to the British police, and in his testimony to Yad Vashem, and in his book, and in his NKVDs statement which had been made in 1944, and discovering small but definite differences in each account.

Regarding the killing of Mir Barlas, it seems likely that the truth was that Sawoniuk had said something to Blustein along the lines that he gave in his first examination, something like 'Mir Barlas was very courageous before he was shot'. This was the story Blustein had told to the British police, to the Magistrates' Court and to Nutting. In this cross-examination he changed his story, claiming that Andrusha had used the words 'I liquidated him'. Because he had changed his testimony, even though he claimed that it was 'holy', the 
judge ruled that Blustein's evidence could not be relied upon to make a safe conviction. It is interesting that in his many accounts of events in Domachevo, Blustein had never mentioned the fact that Andrusha had confessed to the murder of Mir Barlas. Is it possible that Blustein invented this incident after he knew who the defendant was? That was Clegg's inference in crossexamination. And Blustein's answer? Who cares? 'I could even now give you more names of people he killed that I haven't mentioned . . .' The jury in a murder trial heard this accusation. It was entirely 'inadmissible', and entirely 'prejudicial', and probably also true.

\section{Testimony and denial}

The court moved on to hear the evidence of the non-Jewish Belorussians who had travelled from the region of Domachevo to give evidence. They had all been to Britain before for the Magistrates' hearing. Apart from these trips to London, I do not think that any of them had travelled very far from Domachevo during their entire lives. It must have been exciting to be picked out of the crowd, to be made to feel important, to be flown off to London, and to be put up at a nice hotel. Most of the prosecution witnesses spoke Belorussian, and were from Borisy, a tiny hamlet near Domachevo. They were small farmers and their religion was Russian Orthodox.

The first was Mrs Fedora Yakimuk, aged 73. She was the most 'peasantlike' of all the witnesses, small, wrinkled, old, tough and stubborn. Clegg entirely broke her down under cross-examination and made her admit that all her evidence against Sawoniuk was gleaned from the gossip of the village. Yet, strangely, this did not affect her credibility. Clegg made her look ridiculous primarily because she was uneducated, unintelligent, in a wholly foreign country and setting: but not necessarily because she was a liar. The godmother of Yakimuk's nephew, her sister's baby, was Sawoniuk's first wife, Anna Maslova. Yakimuk told the following dramatic story:

I cut my shoulder one day. My mother bound it up. She put iodine on it. The iodine came through the bandage on my arm as a yellow stain. Andrusha saw me and shouted 'Jude, Jude' to make me stop. Andrusha and some Germans dragged me away to be shot. I was crying, begging, 
kissing their feet. I was on my knees explaining I was not a Jew and pleading for my life. Andrusha knew me very well but he didn't protect me. The German pulled off the bandage and saw the wound. He let me go. This was one week after the massacre. (2/03/99)

It is a great story, and the press loved it. Headline in The Times: 'Sawoniuk stood by as I begged for life' (Jones 1999: 5). Undoubtedly it could be true, and for this reason, it is a powerful story.

Ivan Baglay told the story that related to count one of the indictment. Of the four counts, it was by far the strongest. Baglay and a friend, now dead, had been doing a little looting in the ghetto after the main massacre. Sawoniuk had caught them and marched them off to the police station.

B We thought that we were going to be shot. When we came out of the police station we saw three Jews. We realised that we would not be shot but would be burying them. We went directly to the sand hills.

$\mathbf{N}$ Where did you first see the Jews?

в They were standing by a hole that had been dug out. There were three Jews, two men and one woman. Andrusha ordered them to undress. The men were about 40 . They undressed. The woman, about 28 , was reluctant to take her pants off. Andrusha insisted. Andrusha threatened her with a beating. The Jews were emaciated and unshaven. Andrusha shot the Jews in the back of the head. Baglay and friend were told to bury the bodies and that they could take the clothes.

N Who shot the Jews?

B Andrusha

$\mathrm{N}$ With what?

B With the pistol in the back of the head.

$\mathrm{N}$ Did they fall into the pit?

B Yes. One after the other.

N Where was Andrusha?

B Standing behind each. (5/03/99)

The last witness, Fedor Zan, told of the incident that related to Count 3 of the indictment. He was visiting his sister in Kobelka, a nearby village, on his way 
home from work. As he was making his way there from the train station, through the woods, he heard crying and shouting. He saw a group of about 15 Jewish women undressing on the instructions of Sawoniuk. Sawoniuk lined them up next to a pit, and shot them with a machine gun. When the court had visited Domachevo, Zan had taken it to the spot where he had hidden and he had shown the jury the spot where he says he saw Sawoniuk shooting the women. The defence and the prosecution agreed that the distance was 127 or 128 paces. The jury had to decide whether an identification at that distance was safe. In the end they decided that it was, and found Sawoniuk guilty on this count. By the time the jury considered this count, they had reason enough to want to find Sawoniuk guilty; but an identification at such a distance and such a length of time after the event must surely be open to some reasonable doubt.

Under cross-examination Sawoniuk was simply absurd. He routinely denied everything. He denied things which he did not need to deny and which every witness had agreed upon. He denied things which were clearly established historical fact. For example, he began by denying the existence of the ghetto in Domachevo. So Nutting asked him whether there was a ghetto in Tomashevska, which he also denied, and in Brest, which he also denied. He denied that there was barbed wire round the ghetto. He denied that he had ever seen Jews wearing yellow stars. He denied that there were any greater restrictions on Jews than on anyone else. He claimed that the police station was moved to a building just opposite the gate of the ghetto just by coincidence (even though, of course, there was no ghetto). The one issue that made him really lose his temper was the accusation that he had been a member of the ss after he left Domachevo. He told a long and certainly fictional story about how he travelled from Domachevo to France to join the Free Polish Army. Nutting was able to confront him with the Polish army document which showed this story to be untrue, but it was one which could not be legally authenticated. Therefore, it was only of use to the prosecution if Sawoniuk could be persuaded to, or tricked into, authenticating it himself.

Nutting Were you serving in the German army? 
Sawoniuk I never ever joined the German army.

N We've had that document translated. What it says is $1 / 8$ to $11 / 111944$

'German army according to his own statement.'

s (angry) Prove it me in black and white. Rubbish.

N Why does it say so?

s You are lying in front of the jury, everybody. I hope the jury doesn't believe you.

N Look at exhibit 7. Did you ever join the Waffen Border Regiment of the SS?

s (very angry) You call me liar twice. I call you liar.

Judge: Yes, but did you or didn't you?

s Never. Don't talk to me about German army. I won't answer no more questions about German army.

On the document...

$\mathbf{N}$ How is it that a German SS document contains your name, date of birth, place of birth and the word Nina S?

Sawoniuk, shouting, pointing at Griffiths, the Detective from the Metropolitan Police War Crimes Unit and the other policeman at the back of the court: He printed it!

$\mathbf{N}$ This is a Scotland Yard conspiracy?

s Yes. Probably.

N All part of the KGB conspiracy?

s They work together innit?

N Are you tired, Mr Sawoniuk?

s I'm tired enough of you! (22/03/99)

Nearly all of the things Sawoniuk lied about were not centrally important to the counts with which he was charged. Did he kill the 16 women in the Forest as Zan said, and did he kill the three Jews and force Baglay to bury the bodies? These were the only crucial questions remaining after the other two counts had been stopped by the judge from going before the jury. ${ }^{6}$ 
Clegg's closing speech was interesting and, since by this time Sawoniuk seemed to have very little case left, was surprisingly compelling. He noticed that all of the important witnesses, all of the witnesses who testified to having seen Sawoniuk committing atrocities, came from Borisy. All of the witnesses who came from Domachevo itself, while providing useful and absolutely believable background information, did not tell of having seen Sawoniuk actually commit any crimes. But every single person from Borisy who was alive during the war, and is still alive today, gave evidence of particular crimes carried out by Andrusha. Clegg argued that this was too much of a coincidence. Therefore, there must have been either some sort of Borisy conspiracy, or some sort of communal action which was based on the Borisy collective memory or gossip of war time and of Andrusha's involvement. And he gives a reason why Sawoniuk would be particularly hated in Borisy, a hamlet consisting of no more than 30 houses. Borisy was a partisan village, and Sawoniuk freely admitted to having killed partisans. Also, Clegg pointed out that Yakimuk, Melaniuk, and Alexander Baglay had not mentioned important parts of the stories they told about Andrusha in court at the time of the first British police interviews, so they told new and important information only when they knew who the suspect was. And further still, there was much media interest in Domachevo concerning Sawoniuk, and much talk about Sawoniuk's guilt. Zan had given interviews to both British and Russian television journalists about Sawoniuk. It is certainly possible that by the time of the trial, it was 'well known' in Borisy as well as Domachevo, that Sawoniuk was guilty, and that it was important for him to be found guilty.

It might, however, be true that the jury had already quietly agreed upon their verdict before Clegg's closing address but after Nutting's, since it was this lunchtime that they were all seen for the first time in the pub across the road from the Old Bailey enjoying alcoholic refreshment. The jury were certainly convinced of the general guilt of Andrei Sawoniuk and the two counts based on the evidence of Alexander Baglay and Fedor Zan enabled them to convict him, which they did. 


\section{Conclusion}

When they gave evidence, both Blustein and Sawoniuk had attempted to wrestle control over their stories from the court. Blustein was mistrustful of the court and its rules; he did not trust the court to hear his evidence fairly and to believe him. He wanted to be in control of the story he told, to tell what he wanted to tell, rather than to be confined and guided by the adversarial system. He did not want to play the game of cross-examination; rather he wanted to be believed. He did not mind if the court was unhappy with one true story; he could tell another true story. It didn't matter to him. Sawoniuk felt that he was cleverer than the court and that he was cleverer than his own lawyers. If only he could have a chance to tell his story to the jury then they would believe him. He thought that he could talk his way out of the Old Bailey, as he had, presumably, talked his way out of many a tight spot before.

Both of the men, the one who, as a young man, had seen everybody he knew killed, and the one who, as a young man, had taken part in that killing, felt that they could circumvent the rules and norms of the court. They both wanted to talk straight to the jury and they did find ways of doing so. They might have done better if they had trusted the court more, if they had attempted to use the rules of the court in their favour rather than attempting to rise above those rules. Blustein might have avoided having the count that was based on his testimony thrown out if he had trusted the court to believe his original evidence of an indirect confession; it was because he did not trust the court to do so that he embellished it with his claim that Sawoniuk made a direct confession. Sawoniuk would have avoided showing himself so clearly to be a liar. On more than one occasion during his cross-examination, Nutting was happy to allow Sawoniuk to speak directly to the jury without intervention. He would have had more chance of success if he had exercised the right to silence which was offered to him by the law, than by following his strategy of trying to communicate in an unmediated way with the jury.

On the other hand, it might be that the jury was swayed as much by evidence which was inadmissible or prejudicial as it was by the evidence upon which it 
was supposed to come to a decision. The witnesses found ways to talk to the jury which were non-legal, which were outside of the formal rules of the court. Blustein presented the jury with his emotional and moving Holocaust memoir. He challenged them to accept it in spite of Clegg's smart cross-examination and the judge's earnest directions. The existence of the jury and the privacy of the jury's discussions are also within the rules and norms of the criminal trial, not outside them. Evidence is given in the presence of the jury so that the jury can assess non-verbal messages from witnesses. They must be able to see the witnesses giving evidence, and enduring the pressure of crossexamination in order to come to a judgement as to their truthfulness. The rules and norms of law insist that the jury must make its judgement not only from the words spoken by the witnesses but also from the ways in which they are spoken. Embedded within the norms and rules of the criminal trial are the mechanisms by which the rules and norms of evidence may be subverted. The extraordinariness of the events with which this trial was concerned accentuated the difficulties that the trial process has with abstracting and shaping events in the world so that they can be judged in the court room.

\section{Notes}

This account is based on my own observations of the trial. Quotations are from my own notes. They are not a word-for-word transcription but they do capture the sense of what was said in court. I would like to thank the Sociological Review for its support. I would like to thank Robert Fine, David Seymour and Alexandra Simonon for their help in the writing of this paper and Julian, Mirjam, Deborah and Judy Hirsh for helping to look after Dora. I would like to thank the staff and students at Lancaster University where I first gave a version of this article. I would also like to thank Fella, Fischel, Rushka and Yidl, members of my family who survived the Holocaust and told their stories.

1 For example, the case of Dusko Tadic, IT-94-1, http://www.un.org/icty

2 Mass organized rape has been specifically recognized in international law, since 22

February 2001, as a crime against humanity. Three Bosnian Serbs were convicted at the International Criminal Tribunal for the former Yugoslavia for crimes against humanity solely for their involvement in organizing mass rape during the war in Bosnia (Osborn, 2001). See 
also the judgment in the Kunarac, Kovac and Vukovic trial, 22 February 2001. The website of the International Criminal Tribunal for the Former Yugoslavia, http://www.un.org/icty/foca/ trialc2/judgement/index.htm.

3 For a discussion about individual criminal responsibility for crimes against humanity, see Fine and Hirsh, 2000.

$4 \quad$ Interview conducted by the author in The Hague, 21 April 1999.

5 A forerunner of the KGB.

6 Count 2, the killing of a Jew called Shlemko, was not allowed to go before the jury

because the witness admitted that his identification of Sawoniuk was based on hearsay.

\section{References}

Le Monde (2001) 'Génocide rwandais: les quatre accusés reconnus coupables', 8 June. Paris.

Adorno, T. W. (1973) Negative Dialectics. London: Routledge and Keegan Paul.

Arendt, H. and K. Jaspers (1992) Correspondence. 1926-1969. New York: Harcourt

Brace. Arendt, H. (1994) Eichmann in Jerusalem: A Report on the Banality of Evil.

Harmondsworth: Penguin.

Bauman, Z. (1993) Modernity and the Holocaust. Oxford: Polity.

Fine, R. (2000) 'Crimes against humanity: Hannah Arendt and the Nuremberg Debates', European Journal of Social Theory 3(3): 293-311.

Fine, R. and D. Hirsh (2000) 'The Decision to Commit a Crime against Humanity', in M. Archer and J. Tritter (eds) Rational Choice Theory: Resisting Colonization. London: Routledge.

Finkielkraut, A. (1992) Remembering in Vain the Klaus Barbie Trial and Crimes Against Humanity. New York: Columbia University Press.

Habermas, J. (1991) 'Historical Consciousness and Post Traditional Identity', in J. Habermas (ed.) The New Conservatism. London: Polity.

Jones, T. (1999) 'Sawoniuk stood by as I begged for life', The Times, 3 March. London, p. 5.

Judgement in the Kunarac, Kovac and Vukovic trial, 22 February 2001, The website of the International Criminal Tribunal for the Former Yugoslavia. http://www. un.org/icty/foca/trialc2/judgement/index.htm.

Kirchheimer, O. (1969) Political Justice - The Use of Legal Procedure for Political Ends. Princeton, NJ: Princeton University Press.

Lanzmann, C. (1985) Shoah. A film. Paris: Les Films Aleph.

Levi, P. (1987) If This is a Man. London: Abacus.

Osborn, A. (2001) 'Mass Rape Ruled a War Crime', the Guardian, 23 February. London.

Stone, D. (2000) 'Holocaust Testimony and the Challenge to the Philosophy of History', pp.

219-34 in R. Fine and C. Turner (eds) Social Theory After The Holocaust. Liverpool:

Liverpool University Press. pp. 219-34. 